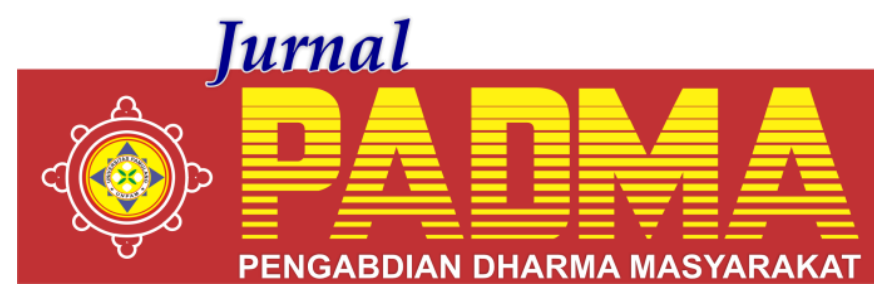

VOLUME 1, NOMOR 3, JULI 2021

\title{
PERANAN SUMBER DAYA MANUSIA DALAM MENINGKATKAN PERILAKU HIDUP BERSIH DAN SEHAT DI MASA PANDEMI
}

\author{
1*Mia Agustiani, , 2 Mochamad Rizki Fajari, ${ }^{3}$ Muhammad Khoiru Sandi, \\ ${ }^{4}$ Faradilla Alfi Hasanah, ${ }^{5}$ Nathayang Fadzrina \\ Universitas Pamulang, Tangerang Selatan, Banten, Indonesia \\ *miaagustiani99@gmail.com
}

\begin{abstract}
Abstrak
Pengabdian ini bertujuan untuk memberikan edukasi kepada masyarakat sekitar Yayasan Aulia RT 003, Serua agar bisa menerapkan PHBS dengan baik dan benar, sebagai salah satu upaya menjaga akselerasi perubahan perilaku kesehatan yang terjadi akibat pandemi CoVid-19. Secara khusus tujuan yang ingin dicapai adalah: (1) meningkatkan partisipasi masyarakat dalam edukasi pola hidup sehat dan bersih untuk mewujudkan masyarakat yang sehat, (2) meningkatkan kesadaran masyarakat untuk secara mandiri dalam mencegah dan menanggulangi masalah-masalah kesehatan yang dihadapinya dan (3) meningkatkan pengetahuan keterampilan dalam membuat makanan dan minuman kesehatan yang sehat tapi murah, dan banyak tersedia di sekitar lingkungan masyarakat sebagai upaya pencegahan pada beberapa penyakit pasca pandemi CoVid-19.
\end{abstract}

Kata Kunci: PBHS, Pandemi CoVid-19, Lingkungan

\section{Abstract}

This service aims to provide education to the community around the Yayasan Aulia RT 003, Serua so that they can implement Clean and Healthy Living Behavior properly and correctly, as an effort to accelerate changes in health behavior that have occurred due to the CoVid-19 pandemic. Specifically, the objectives to be achieved are: (1) increasing public participation in education on healthy and clean lifestyles to create a healthy society, (2) increasing public awareness to independently prevent and overcome health problems it faces and (3) increase knowledge of skills in making health food and drinks that are healthy but inexpensive, and widely available in the community as a preventive measure for several post-pandemic CoVid-19 diseases. Keywords: PBHS, Pandemic CoVid-19 Diseases, Environment

\section{PENDAHULUAN}

Kegiatan pengabdian masyarakat merupakan salah satu Tri Dharma Perguruan Tinggi Selain Pendidikan dan Penelitian, sesuai undang-Undang RI Nomor 20 Tahun 2003 tentang Sistem Pendidikan Nasional, pada Pasal 20 ayat 2 dinyatakan: "Perguruan Tinggi berkewajiban menyelenggarakan pendidikan, penelitian dan pengabdian masyarakat". Pada Pasal 24 ayat 2 disebutka. "Perguruan tinggi memiliki otonomi untuk mengelola sendiri lembaganya sebagai pusat penyelenggaraan pendidikan tinggi, penelitian ilmiah, dan pengabdian masyarakat".

Pengabdian kepada masyarakat merupakan pelaksanaan pengamalan ilmu pengetahuan, teknologi dan seni budaya langsung pada masyarakat secara kelembagaan melalui metodologi ilmiah sebagai penyebaran Tri Dharma Perguruan Tinggi serta tanggung jawab yang luhur dalam usaha mengembangkan kemampuan masyarakat, sehingga dapat mempercepat laju pertumbuhan tercapainya tujuan pembangunan nasional.

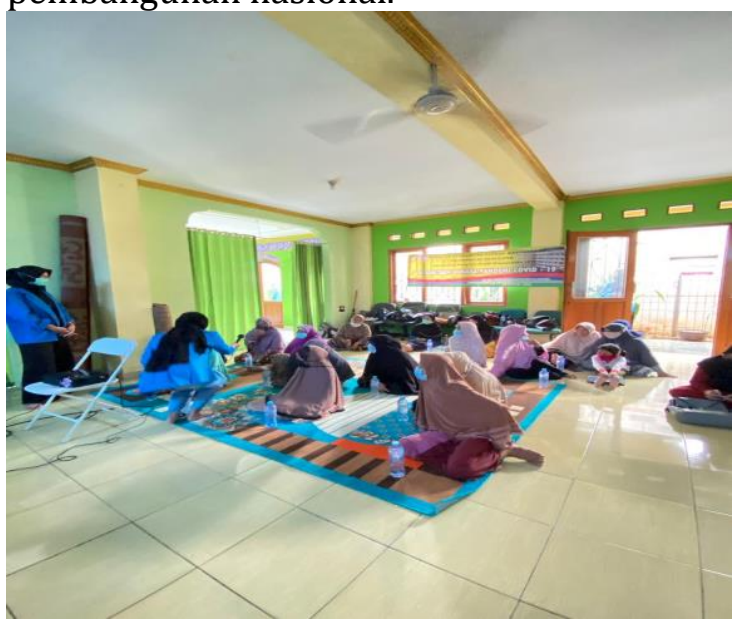




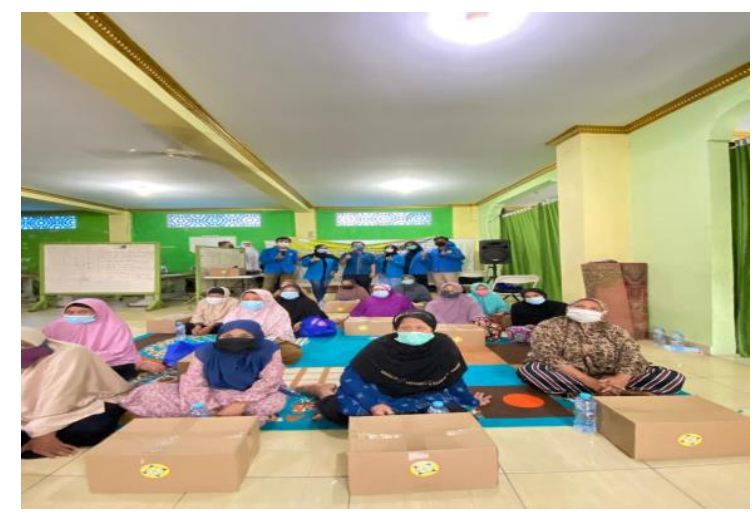

Gambar 1. Kegiatan Pengabdian Kepada Masyarakat

Program pengabdian kepada masyarakat merupakan salah satu program yang wajib dilaksanakan, baik oleh dosen maupun oleh mahasiswa, dengan berlandaskan pada prinsip-prinsip: motivasi pemenuhan kompetensi akademik, jiwa kewirausahaan (entrepreneurship), dan profesional serta kesehatan masyarakat khususnya anak-anak calon penerus bangsa, sehingga dapat menghasilkan program pengabdian kepada masyarakat yang bermutu, relevan, dan sinergis dalam meningkatkan pemberdayaan masyarakat.

Manajemen merupakan salah satu program studi di Universitas Pamulang. Program studi ini memiliki andil dalam mencetak lulusan yang berkarakter serta mampu bersaing di dalam dunia kerja, serta dapat berperan bagi pembangunan.

Kesehatan adalah keadaan sejahtera dari badan, jiwa dan sosial yang memungkinkan setiap orang hidup produktif secara sosial dan ekonomi. Perilaku hidup bersih sehat adalah upaya untuk memberikan pengalaman belajar atau menciptakan suatu kondisi bagi perorangan, keluarga, kelompok dan masyarakat, dengan membuka jalur komunikasi, memberikan informasi dan melakukan edukasi untuk meningkatkan pengetahuan, sikap dan perilaku melalui pendekatan pimpinan (advocacy), bina suasana (social support) dan pemberdayaan masyarakat (empowerment). Masyarakat dapat mengenali dan mengatasi masalahnya sendiri dan dapat menerapkan cara-cara hidup sehat dengan menjaga, memelihara dan meningkatkan kesehatannya (Notoatmodjo, 2007).

Penerapan kebersihan diri di masyarakat merupakan tanggung jawab setiap orang yang juga menjadi tanggung jawab pemerintah beserta jajaran sektor terkait untuk memfasilitasi kegiatan ini di masyarakat agar dapat dijalankan secara efektif. Kondisi sehat dapat dicapai dengan mengubah perilaku dari yang tidak sehat menjadi perilaku sehat serta menciptakan lingkungan sehat, oleh karena itu kesehatan perlu dijaga, dipelihara dan ditingkatkan oleh setiap anggota rumah tangga serta diperjuangkan oleh semua pihak (Nurmahmuda, 2018).

Coronavirus Disease 2019 adalah penyakit jenis baru yang belum pernah diidentifikasi sebelumnya pada manusia. Dua cara utama transmisi virus CoVid-19 adalah percikan (droplet) saluran pernapasan dan kontak. Percikan saluran pernapasan dihasilkan saat seseorang batuk atau bersin. Setiap orang yang berada dalam kontak erat (dalam radius $1 \mathrm{~m}$ ) dengan orang yang menunjukkan gejala-gejala gangguan pernapasan (batuk, bersin) berisiko terpapar percikan saluran pernapasan yang kemungkinan dapat menyebabkan infeksi (infeksius). Percikan juga dapat jatuh ke permukaan benda di mana virus tetap aktif. Oleh karena itu, lingkungan sekitar terdekat dari orang yang terinfeksi dapat menjadi sumber penularan (WHO, 2020).

Pada Masa pandemi corona atau CoVid-19, penting bagi kita untuk melakukan berbagai tindakan pencegahan, termasuk menjaga jarak sosial, tetap tinggal di rumah, menerapkan perilaku hidup bersih dan sehat, gerakan menggunakan masker, serta Penggunaan Antiseptik dan Desinfektan dalam kehidupan sehari-hari. Mata pencaharian masyarakat tersebar merata mulai dari pedagang, guru/dosen dan wiraswasta. Oleh karena itu dengan adanya program pengabdian kepada masyarakat Tematik ini diharapkan terbentuk model masyarakat yang paham tindakan pencegahan CoVid-19.

Maka dari itu kelompok kami melakukan peyuluhan tentang Peranan Sumber Daya Manusia dalam Meningkatkan Perilaku Hidup Bersih dan Sehat di masa Pandemi di Jl. Hj. Mida Serua Utara, Bojong Sari, Depok. 


\section{METODE}

Penyuluhan merupakan metode yang kami rasa tepat dalam pelaksanaan Pengabdian Kepada Masyarakat di Yayasan Aulia. Seperti yang sama-sama kita ketahui, tingkat kesadaran masyarakat untuk peduli terhadap kesehatan dan kebersihan lingkungan semakin menurun padahal pandemic CoVid-19 masih ada di Indonesia.

Oleh karena itu, tujuan kami dalam penyuluhan ini adalah untuk mengedukasi tentang pentingnya menjaga kebersihan dan kesehatan diri serta lingkungan, pemutaran video mencuci tangan dengan benar, serta demonstrasi untuk selalu memakai masker saat keluar rumah dan pemakaian handsanitizer untuk dapat menjaga dari paparan virus dimasa dan setelah pandemi CoVid-19.

\section{HASIL DAN PEMBAHASAN}

Pelaksanaan kegiatan yang akan dilakukan untuk mengatasi permasalahan adalah sebagai berikut :

Materi penyuluhan adalah meningkatkan hidup bersih dan sehat di masa pandemic Co-Vid 19. Tujuan dari penyuluhan ini adalah memberikan ilmu dan wawasan baru kepada Warga RT 003 Serua, tentang pentingnya menjaga kesehatan diri dan lingkungan serta menjaga kebersihan selama masa pandemi, sehingga tumbuh minat dan motivasi dari diri mereka untuk melaksanakannya dengan baik dan benar.

Disamping itu juga disajikan video $3 \mathrm{M}$ (mencuci tangan, memakai masker dan menjaga jarak) bertujuan agar Warga RT. 003 Serua dapat melihat secara visual bukan hanya dari penyampaian materi kelompok kami. Selain itu, penyuluhan ini disampaikan dengan bentuk presentasi dan tanya jawab kepada Warga RT 003 Serua.

Persiapan kegiatan ini berupa penentuan materi yang akan disampaikan dan pembuatan slide presentasi yang menarik. Pada persiapan pelaksanaan penyuluhan, Tim PKM kami melakukan pengecekan terhadap soundsystem, microfon, projector dan laptop yang akan digunakan untuk presentasi, sehingga pelaksanaan penyuluhan dalam pemaparan materi serta pemutaran video edukasi $3 \mathrm{M}$ dapat berjalan dengan baik dan mendapatkan feedback yang optimal terhadap Warga RT 003 Serua.

Dengan adanya kegiatan Pengabdian Kepada Masyarakat ini dapat meningkatkan rasa waspada dan peduli dari Warga RT 005 Serua terhadap kesehatan dan kebersihan diri serta lingkungan khususnya di masa pandemic. Jika hal ini dilaksanakan dengan tepat tentunya akan menimbulkan efek positif juga bagi warga sekitar yang akan ikut serta melaksanakan PHBS berdasarkan kebiasaan hidup sehat yang dilaksanakan oleh Warga RT 003 Serua.

\section{PENUTUP}

Acara kegiatan Pengabdian Kepada Masyarakat ini dilaksanakan selama satu hari, pada Minggu, 21 Maret 2021 sebagai berikut : Pertama, Pembukaan oleh Ketua Yayasan Aulia, kemudian dilanjutkan laporan dari Ketua Pelaksana sekaligus penjelasan penyuluhan. Kedua yaitu penyuluhan (pemaparan materi dan pemutaran video edukasi $3 \mathrm{M}$ ) oleh Tim PKM kami beserta sesi tanya jawab kepada Warga RT 003 Serua. Ketiga, pembagian cinderamata dan bingkisan untuk Warga RT 003 Serua yang sudah berpartisipasi.

\section{DAFTAR PUSTAKA}

Nurjaya, N., et al. (2021). Pengaruh Kompetensi Sumber Daya Manusia Dan Kemampuan Pemanfaatan Teknologi Terhadap Kinerja Aparatur Desa Pada Kantor Kepala Desa Di Kabupaten Gunung kidul, Yogyakarta. JENIUS Ournal Ilmiah Manajemen Sumber Daya Manusia), 4(3), 332-346.

Suryani, N. L., et al. (2020). The Analysis of Career Development and Placement of Employee Performance in Pt. Global Means of Transindo in Jakarta. Solid State Technology, 63(6), 1382-1389.

http://kotaku.pu.go.id:8081/wartaarsipdeti l.asp? $\mathrm{mid}=8599 \&$ catid $=2 \&$

https://dikti.kemdikbud.go.id/kabardikti/kabar/peran-perguruan-tinggidalam-pencegahan-danpengendalian-covid-19-di-indonesiamelalui-kampus-sehat/

https://kkn.unnes.ac.id/lapkknunnes/3200 433290910156 Kelurahan\%20Pasa rbatang 20201003 110648.pdf 